\title{
Comparative Advantages in Attracting Investments - Contemporary View
}

\author{
Assoc. Prof. Dr. Evgenia Tonkova \\ University of Economics - Varna, Varna, Bulgaria \\ tonkova@ue-varna.bg \\ Chief Assist. Prof. Dr. Sevdalina Hristova \\ University of Economics - Varna, Varna, Bulgaria \\ s.hristova@ue-varna.bg \\ Assoc. Prof. Dr. Dancho Petrov \\ University of Economics - Varna, Varna, Bulgaria \\ dpetrov@ue-varna.bg
}

\begin{abstract}
Knowledge of the comparative advantages of territorial units and their proper use to attract investments is important for the development of all countries. The specific comparative advantages that underpin investment attraction policies need to be clearly articulated and communicated. Integrated policies at the territorial unit level can be used as a tool in the effort to overcome the territorial and sectoral imbalance of investment activity and socio-economic development. The focus of the study is on the comparative advantages in attracting investments and their recognition by municipal administrations in Bulgaria. Specific recommendations are proposed to improve the balance of investments and the mechanisms for their management.
\end{abstract}

Keywords: comparative advantages, investments, imbalance

JEL Code: E22, R11 DOI: https://doi.org/10.36997/IJUSV-ESS/2020.9.3.12

\section{Introduction}

The comparative advantages in attracting investments at the level of countries and municipalities have been in the focus of researchers in recent years. Increased competition between territorial units and the rethinking of the factors that influence the locational decisions of investors bring to the fore the question of knowing the comparative advantages of municipalities and their use to improve the socio-economic life in a high-tech environment. The change in the prioritization of the individual locational determinants concerning investments opens new opportunities for attracting investments and gives a chance for a more even distribution of investments on the territory at the national and municipal level. In addition to this aspect of the comparative advantages, the literature also examines the feedback and how foreign direct investment can change the revealed comparative advantage of the host economy (Freund \& Moran, 2017).

\section{Comparative advantages and attraction of investments}

One shared opinion in economics is that each country holds specific advantages compared to other countries, which is explained by the imbalance in terms of natural resources, population demographics, and chronological point of economic and technical development (Nguyen, 2011). In addition to the individual countries and groups of countries level, the comparative advantages can also be considered from the point of view of individual municipalities, as municipalities also compete in attracting domestic and foreign investors.

The indicators (Table 1) that are taken into account when localizing investments include the indicators of the level of education of the population. It is believed that the higher educational status of the population will contribute to better results from the invested funds. However, another point of view is possible: the search for a less educated population, which can be explained by the specifics of the intended business, which may not require high qualifications. An OECD study shows that Sweden's main comparative advantage is in knowledge-intensive activities. The study emphasizes 
the importance of investing in skills and education to foster growth and contain inequalities (OECD, 2015). Positive transfer effects of the accumulation of human capital are also discussed. It is argued that such accumulation has a positive impact on the quality of labour which increases factor productivity creating a comparative advantage (Dirk Willem te Velde, 2005).

The state of the infrastructure is also included as an indicator of comparative advantages. A number of studies examine the relationship between the state of the infrastructure and the size and type of the investments. Another source of comparative advantage may be the traditions in the production of certain products and services in increased demand globally. The shortage in their supply and the growth in the demand worldwide can increase the investment interest in places with comparative competitive and production advantages. For example, persistent food shortages in many countries will direct some of the investments to countries with traditions and appropriate conditions for agriculture and processing industries.

Despite the development of new technologies, the advantages of the location remain among the top indicators of comparative advantages. Climatic features, accessibility and sociodemographic characteristics continue to be a guide in the distribution of investments throughout the territory.

In addition to the sources of competitive advantages considered, state and municipal policies for promoting investment activity are also important for attracting investments. Researchers focus on the implications of comparative advantage for foreign direct investment (FDI) incentives (Qiu, 2003) and importance of FDI promotion to foster comparative advantage in a given product category (Harding et al., 2013). From the practices of investor attraction it can be concluded that it is not enough simply to identify the comparative advantages; these must be promoted in an appropriate manner through selected communication channels. Special attention is paid to the role of "national policies (infrastructure, export promotion, education and training, and R\&D policy related to export industries) in creating and sustaining comparative advantage" (Gupta, 2015).

Table 1. Comparative advantages in the focus of contemporary researchers

\begin{tabular}{|l|l|l|}
\hline \multicolumn{1}{|c|}{ Study } & \multicolumn{1}{|c|}{ Comparative advantage } & \multicolumn{1}{c|}{ Highlights } \\
\hline $\begin{array}{l}\text { Spiros Bougheas } \\
\text { Richard Kneller } \\
\text { Raymond G. Riezman } \\
(2011)\end{array}$ & $\begin{array}{l}\text { Higher levels of education in the } \\
\text { host population }\end{array}$ & $\begin{array}{l}\text { Education policies affect an } \\
\text { economy's skill distribution, its } \\
\text { competitiveness and patterns of } \\
\text { trade }\end{array}$ \\
\hline Nguyen, H. T. (2011) & $\begin{array}{l}\text { Production, technological levels, } \\
\text { managerial skills, and financial } \\
\text { ability }\end{array}$ & Effects on FDI \\
\hline Krista Tuomi (2012) & $\begin{array}{l}\text { Investment allowances and } \\
\text { accelerated depreciation }\end{array}$ & $\begin{array}{l}\text { These are typical of } \\
\text { industrialized countries }\end{array}$ \\
\hline $\begin{array}{l}\text { ASEAN Investment } \\
\text { Report (2018) }\end{array}$ & $\begin{array}{l}\text { Locational advantages (i.e. } \\
\text { domestic market size, economic } \\
\text { growth, opportunities to benefit } \\
\text { from economies of scale and } \\
\text { lower production costs) }\end{array}$ & $\begin{array}{l}\text { Influence on a group's } \\
\text { investment location choices }\end{array}$ \\
\hline $\begin{array}{l}\text { OECD / World Trade } \\
\text { Organization (2019) }\end{array}$ & $\begin{array}{l}\text { Key source of comparative } \\
\text { advantage - typically low-cost } \\
\text { labour in developing countries }\end{array}$ & $\begin{array}{l}\text { Special economic zones have } \\
\text { proved successful when they } \\
\text { attract investment that exploits }\end{array}$ \\
\hline $\begin{array}{l}\text { Baldomero-Quintana } \\
\text { (2020) }\end{array}$ & Infrastructure & $\begin{array}{l}\text { Assesses how a new road } \\
\text { infrastructure project can change } \\
\text { the national comparative } \\
\text { advantage }\end{array}$ \\
\hline
\end{tabular}


The success of the investors is largely influenced by the conditions at the point of investment, but another important factor is the practical utilisation of the identified comparative advantages of the territory by the company management. In this regard, the conclusion is drawn that "a firm's international competitiveness is a complex phenomenon which is shaped by both firmlevel advantages and country-level advantages" (Szałucka, 2015).

\section{Bulgaria in the focus of investor interest - investments and their balancedness}

Bulgaria's comparative advantages in attracting investments are undergoing transformations over time. The data for the country at the time of the study highlight comparative advantages in attracting investment in several areas: strategic location, cost of business, attractive taxation system (corporate and personal income tax), well-developed and balanced educational system and IT sector progress.

Of interest are the results reported for attracting foreign direct investment in Bulgaria in the period 2014-2018 according to official data from the National Statistical Institute (NSI).

Several positive trends can be identified during the study period. In Bulgaria, there is an increase in FDI in non-financial sector enterprises from EUR 24.5 billion in 2017 to EUR 25.5 billion in 2018 (according to NSI data). The second positive trend is that the total amount of foreign direct investment as a share of GDP remains relatively constant. A change in the sectoral structure of FDI is also observed (Table 2).

The largest share of foreign direct investment during the analysed period was in the Processing Industry sector, with a steady upward trend in its relative share. In second place is the Trade, Transport, Hotels and Restaurants sector, where there is also an increase of four percentage points between the first and the last year of the period. Throughout the above period the Real Estate Transactions and Production and Distribution of Electricity, Heat and Gaseous Fuels sectors remain in third and fourth place, respectively, and both sectors saw relatively constant values. A significant decrease both in absolute value and as a relative share was observed in foreign direct investment in the Construction sector. In two economic sectors, namely Agriculture, Forestry and Fishery and Culture, Sports and Entertainment, less than $1 \%$ in total of foreign direct investment was received in 2018 on average for the year.

Table. 2. Sectoral structure of foreign direct investments in non-financial corporations by economic activities for the period 2014-2018

\begin{tabular}{|c|c|c|c|c|c|c|}
\hline No & Economic sectors & 2014 & 2015 & 2016 & 2017 & 2018 \\
\hline 1. & Agriculture, forestry and fishery & $0.79 \%$ & $0.52 \%$ & $0.39 \%$ & $0.32 \%$ & $0.25 \%$ \\
\hline 2. & Processing industry & $23.26 \%$ & $23.64 \%$ & $25.30 \%$ & $28.03 \%$ & $29.03 \%$ \\
\hline 3. & $\begin{array}{l}\text { Production and distribution of electricity, } \\
\text { heat and gaseous fuels }\end{array}$ & $12.55 \%$ & $13.28 \%$ & $12.57 \%$ & $11.48 \%$ & $11.69 \%$ \\
\hline 4. & Construction & $4.25 \%$ & $3.50 \%$ & $2.82 \%$ & $2.90 \%$ & $2.14 \%$ \\
\hline 5. & Trade, transport, hotels and restaurants & $23.10 \%$ & $25.93 \%$ & $27.18 \%$ & $26.48 \%$ & $26.99 \%$ \\
\hline 6. & $\begin{array}{l}\text { Creation and dissemination of } \\
\text { information and creative products; } \\
\text { telecommunications }\end{array}$ & $8.11 \%$ & $8.16 \%$ & $8.49 \%$ & $7.82 \%$ & $8.32 \%$ \\
\hline 7. & Real estate transactions & $14.11 \%$ & $14.91 \%$ & $14.53 \%$ & $14.61 \%$ & $15.32 \%$ \\
\hline 8. & Culture, sports and entertainment & $0.39 \%$ & $0.55 \%$ & $0.58 \%$ & $0.64 \%$ & $0.51 \%$ \\
\hline 9. & Other sectors & $13.44 \%$ & $16.84 \%$ & $17.06 \%$ & $21.15 \%$ & $21.23 \%$ \\
\hline
\end{tabular}

Source: calculations by the authors based on data from the INFOSTAT Information System of the NSI, https://infostat.nsi.bg 
It can be summarized that foreign investors are withdrawing from the sectors construction and agriculture. At the same time, the share of FDI in the manufacturing sectors is growing.

The balancedness of investments throughout the territory of Bulgaria can be assessed not only by the level of investments by economic sectors, but also by the territorial distribution of investments at the level of districts, where the imbalances are clearly visible. In the last year of the study period (2018) nearly half of the total volume of foreign direct investments was concentrated in the Sofia-city district.

The volume of foreign investments per capita at the district level also shows disproportions and imbalances in the territorial distribution. Only in four districts the level of investments is above the national average, with the highest value reported for the capital (Table 3). In the remaining 24 districts the level of investments is below the national average. The total investments per capita in the fourteen districts with the lowest volume of investments per capita are below the level of investments in the capital. The comparative analysis of the average values of this indicator shows that in the district of Montana, where the lowest value for the period was reported, the investments per capita are over 35 times less than those in the capital and about 13 times less than the average for Bulgaria.

Regional disparities are also observed in the growth rates of FDI by districts during the analysed period. With an average rate of change for the country of $18.8 \%$, the districts with the highest growth rate - Haskovo and Dobrich, reported values of $210.5 \%$ and $193.9 \%$, respectively. At the same time, seven districts reported a negative growth rate during the period.

Table. 3. Foreign direct investments in non-financial enterprises per capita by districts for the period 2014-2018 (in EUR/person)

\begin{tabular}{|l|r|r|r|r|r|r|r|}
\hline \multicolumn{1}{|c|}{ District } & $\mathbf{2 0 1 4}$ & $\mathbf{2 0 1 5}$ & $\mathbf{2 0 1 6}$ & $\mathbf{2 0 1 7}$ & $\mathbf{2 0 1 8}$ & \multicolumn{1}{c|}{$\begin{array}{c}\text { Average for } \\
\text { the period }\end{array}$} & \multicolumn{1}{c|}{$\begin{array}{c}\text { Rate of } \\
\text { change }\end{array}$} \\
\hline $\begin{array}{l}\text { Average for } \\
\text { the country }\end{array}$ & 2997 & 3238 & 3310 & 3472 & 3560 & 3315 & $18.8 \%$ \\
\hline Sofia (capital) & 8868 & 9177 & 9226 & 9288 & 9361 & 9184 & $5.6 \%$ \\
\hline Sofia & 5205 & 5374 & 5611 & 6323 & 6064 & 5715 & $16.5 \%$ \\
\hline Burgas & 2263 & 4118 & 4231 & 4586 & 5019 & 4043 & $121.8 \%$ \\
\hline Varna & 3544 & 3724 & 3777 & 4122 & 3968 & 3827 & $12.0 \%$ \\
\hline Stara Zagora & 2974 & 3162 & 2866 & 2839 & 2937 & 2,956 & $-1.2 \%$ \\
\hline Gabrovo & 2279 & 2489 & 2694 & 2960 & 3120 & 2708 & $36.9 \%$ \\
\hline Plovdiv & 2289 & 2365 & 2578 & 2829 & 2861 & 2584 & $25.0 \%$ \\
\hline Targovishte & 1703 & 1777 & 1999 & 2177 & 2514 & 2034 & $47.6 \%$ \\
\hline Pazardzhik & 1771 & 1845 & 1842 & 1961 & 2020 & 1888 & $14.1 \%$ \\
\hline Ruse & 1694 & 1493 & 1646 & 1693 & 1964 & 1698 & $15.9 \%$ \\
\hline Pernik & 1724 & 1426 & 1507 & 1667 & 1647 & 1594 & $-4.5 \%$ \\
\hline Blagoevgrad & 1219 & 1427 & 1556 & 1541 & 1636 & 1476 & $34.3 \%$ \\
\hline Kardzhali & 947 & 1165 & 1015 & 1695 & 1908 & 1346 & $101.5 \%$ \\
\hline Dobrich & 610 & 1123 & 1369 & 1534 & 1793 & 1286 & $193.9 \%$ \\
\hline Razgrad & 962 & 894 & 1138 & 1341 & 1564 & 1180 & $62.6 \%$ \\
\hline Lovech & 1004 & 1121 & 1077 & 898 & 969 & 1014 & $-3.5 \%$ \\
\hline Pleven & 1199 & 1121 & 756 & 927 & 524 & 906 & $-56.3 \%$ \\
\hline Vidin & 554 & 853 & 804 & 840 & 953 & 801 & $72.2 \%$ \\
\hline Smolyan & 660 & 744 & 765 & 773 & 860 & 760 & $30.4 \%$ \\
\hline Sliven & 481 & 472 & 654 & 739 & 866 & 643 & $80.0 \%$ \\
\hline Shumen & 593 & 588 & 591 & 623 & 681 & 615 & $14.8 \%$ \\
\hline Vratsa & 788 & 498 & 456 & 657 & 654 & 611 & $-17.0 \%$ \\
\hline
\end{tabular}


IZVESTIA JOURNAL OF THE UNION OF SCIENTISTS - VARNA

\begin{tabular}{|l|r|r|r|r|r|r|r|}
\hline $\begin{array}{l}\text { Veliko } \\
\text { Tarnovo }\end{array}$ & 437 & 497 & 608 & 561 & 597 & 540 & $36.7 \%$ \\
\hline Haskovo & 258 & 446 & 516 & 444 & 801 & 493 & $210.5 \%$ \\
\hline Yambol & 462 & 638 & 462 & 421 & 445 & 486 & $-3.7 \%$ \\
\hline Kyustendil & 340 & 334 & 354 & 353 & 361 & 348 & $6.1 \%$ \\
\hline Silistra & 276 & 254 & 292 & 326 & 257 & 281 & $-6.8 \%$ \\
\hline Montana & 246 & 199 & 275 & 289 & 274 & 257 & $11.7 \%$ \\
\hline
\end{tabular}

Source: calculations by the authors based on data from the INFOSTAT Information System of the NSI, https://infostat.nsi.bg

Despite the disproportionate distribution of FDI, some positive trends can be highlighted. The average growth rate of FDI for the country during the analysed period is $18.8 \%$. In 21 districts there is an increase in investments per capita, and in 13 of them this growth is above the national average. The growth of investments per capita in the capital is 5.6\%. Only in seven districts is there a decline by this indicator.

The identified changes and imbalances raise several important questions. The first question is whether sufficient targeted efforts are being made to attract foreign investors. The second question is whether the district and municipal administrations recognize their comparative competitive advantages and whether they present these in the appropriate way to reach potential investors.

\section{Comparative advantages of the municipalities through the eyes of the local administration}

In November 2019, a survey was conducted (The survey in the publication was conducted within research project N11/2017 "Contemporary aspects in attracting investments for the development of territory") on the approaches and means of attracting investment applied by municipalities in Bulgaria by the respondents method. An electronic self-completion questionnaire was used, including a total of 26 questions, one of which is the question of the comparative advantages of the municipality in attracting investments and investors to their territories (in this paper the results are analysed only for this variable).

Table 4 presents the comparative advantages of the municipalities in attracting investors by frequency of reference.

Table 4. Comparative advantages of municipalities in attracting investors

\begin{tabular}{|ll|r|}
\hline \multicolumn{2}{|c|}{ Comparative advantages } & Percent \\
\hline 1. & Geographical location & $84.8 \%$ \\
\hline 2. & Existing technical infrastructure & $51.5 \%$ \\
\hline 3. & Adequate communication between the municipality and the public & $51.5 \%$ \\
\hline 4. & Successfully implemented investments on the territory of the municipality & $42.4 \%$ \\
\hline 5. & Human resources and demographic characteristics of the municipality & $33.3 \%$ \\
\hline 6. & Well-developed educational infrastructure & $33.3 \%$ \\
\hline 7. & Economic situation in the municipality & $33.3 \%$ \\
\hline 8. & Level of salaries and wages & $27.3 \%$ \\
\hline 9. & Unemployment rate & $18.2 \%$ \\
\hline 10. & Existing and functioning technological, industrial, logistics parks and the & $12.1 \%$ \\
like & & \\
\hline 11. & Existence of industrial clusters & $9.1 \%$ \\
\hline
\end{tabular}

Note: The question "Which do you think are the comparative advantages of your municipality in attracting investors?" allows more than one answer. 
For $84.8 \%$ of the municipalities that participated in the survey, one comparative advantage is their geographical location. In fact, the "geographical location", which is perceived as a classic comparative advantage, is indicated in the first place as an advantage by the majority of municipalities. In second place are the answers "existing technical infrastructure" and "adequate communication with the public" with $51.5 \%$ of the municipalities indicating these advantages. The third place is occupied by "human resources and demographic characteristics of the municipality", "economic situation in the municipality" and "well-developed educational infrastructure", which are mentioned by one third of the municipalities as their comparative advantages.

One interesting aspect is the distribution of the municipalities by number of comparative advantages indicated. Nearly one third of the municipalities indicate only one or two comparative advantages; another nearly $1 / 3$ indicate three or four advantages, and the remaining $1 / 3$ of the municipalities mention between 5 and 9 comparative advantages. Only one of the respondents in the survey states that the municipality has 9 comparative advantages.

\section{Conclusion}

The territorial and sectoral imbalance of the distribution of foreign direct investment and other investments in Bulgaria must be analysed in its various aspects. On the one hand, such imbalance is the result of a systematic accumulation of investments in districts and sectors that prove to be attractive to foreign investors. On the other hand, however, the potential of most municipalities to attract investors has not been harnessed. Although municipal administrations are aware of their traditional comparative advantages, they do not always bring these up to date with the new economic and technological conditions. It is necessary to develop and implement a clear integrated policy for attracting investments throughout the territory of the country, taking into account the specific advantages of each administrative territorial unit. There is a growing need to develop investment management mechanisms that cover the sectoral characteristics of investments and the new trends in the search for competitive advantages, which include the intangible aspects of the competitiveness of the territories.

\section{Acknowledgement}

The present scientific work is funded under Project NPI 11/2017

\section{References}

1. ASEAN (2018) Investment Report 2018 Foreign Direct Investment and the Digital Economy in ASEAN. [Online] Available from: https://asean.org/storage/2018/11/ASEAN-InvestmentReport-2018-for-Website.pdf [Accessed 30/09/2020].

2. Baldomero-Quintana, L. (2020) How Infrastructure Shapes Comparative Advantage. [Online] Available from: https://economics.indiana.edu/documents/JMP_Luis_BQ1.pdf [Accessed 30/09/2020].

3. Bougheas, S., Kneller, R., Riezman, R., (2011) Optimal education policies and comparative advantage. GEP, CES-ifo.

4. Freund, C. and Moran, T.H. (2017) Multinational Investors as Export Superstars: How Emerging-Market Governments Can Reshape Comparative Advantage. Working Paper 17-1, Peterson Institute for International Economics.

5. Gupta, S.D. (2015) Comparative Advantage and Competitive Advantage: An Economics Perspective and a Synthesis. Athens Journal of Business and Economics, 1 (1). pp. 9-22.

6. Harding, T., Javorcik, B.S., Maggioni, D. (2013) FDI Promotion Policy and Comparative Advantage. [Online] Available from: https://www.econ.berkeley.edu/sites/default/files/ HardingJavorcik\%26MaggioniUnpubSept2013.pdf [Accessed 30/09/2020].

7. https://infostat.nsi.bg 
8. Nguyen, H. T. (2011). Attracting and benefiting from foreign direct investment under absorptive capacity constraints : a case for Vietnam. Technische Universiteit Eindhoven.

9. OECD (2015) Economic Surveys Sweden. Overview. [Online] Available from: http://www.oecd.org/economy/surveys/Sweden-2015-overview.pdf [Accessed 30/09/2020].

10. OECD / WTO (2019), Economic diversification: lessons from practice, Aid for Trade at a Glance 2019: Economic Diversification and Empowerment, OECD Publishing, Paris. DOI: https://doi.org/10.1787/f61d8ce8-en.

11. Qiu, L.D. (2003) Comparing Sectoral FDI Incentives: Comparative Advantages and Market Opportunities, Annals of Economics and Finance, 4, pp. 151-176.

12. Szałucka, M. (2015) Does Location Really Matter? The Influence of the fdi Location on Enterprise Competitiveness: The Evidence from Polish Enterprises, Managing Global Transitions, 13 (2). pp. 125-149.

13. Tuomi, K. (2012) Review of Investment Incentives: Best Practice in Attracting Investment. International Growth Centre (IGC).

14. Velde, D.W, te (2005) Globalisation and Education. What do the trade, investment and migration literatures tell us? Working Paper 254. Overseas Development Institute.

15. www.nsi.bg/en/content/17467/\%D0\%BF\%D1\%80\%D0\%B5\%D1\%81\%D1\%81\%D1\%8A\%D0 $\% \mathrm{BE} \% \mathrm{D} 0 \% \mathrm{~B} 1 \% \mathrm{D} 1 \% 89 \% \mathrm{D} 0 \% \mathrm{~B} 5 \% \mathrm{D} 0 \% \mathrm{BD} \% \mathrm{D} 0 \% \mathrm{~B} 8 \% \mathrm{D} 0 \% \mathrm{~B} 5 /$ foreign-direct-investmentsand-expenditure-acquisition-tangible-fixed 